\section{'NASPOT 11', a Sweetpotato Cultivar Bred by a Participatory Plant-breeding Approach in Uganda}

\author{
Robert O.M. Mwanga ${ }^{1,2}$, Charles Niringiye, Agnes Alajo, \\ Benjamin Kigozi, Joweria Namukula, and Isaac Mpembe \\ National Agricultural Research Organization (NARO), National Crops \\ Resources Research Institute (NaCRRI), Namulonge, P.O. Box 7084, Kampala, \\ Uganda
}

\section{Silver Tumwegamire \\ International Potato Center (CIP), Box 22274, Kampala, Uganda}

\author{
Richard W. Gibson \\ Natural Resources Institute, University of Greenwich, Central Avenue, \\ Chatham Maritime, Kent, ME4 4TB, UK
}

\section{G. Craig Yencho \\ Department of Horticultural Science, North Carolina State University, Room 214A Kilgore Hall, Box 7609, Raleigh, NC 27695-760}

Additional index words. seedling screening, sweetpotato breeding, sweetpotato virus disease, Alternaria bataticola blight

The sweetpotato [Ipomoea batatas (L.) Lam.] cultivar NASPOT 11 (Namulonge Sweetpotato 11) was approved for release by the Ugandan Plant Variety Release Committee in Apr. 2010 (Mwanga et al., 2010). This is the fifth time the sweetpotato breeding program in Uganda has officially released sweetpotato cultivars. The program released 19 cultivars between 1995 and 1999 (Mwanga et al., 2009), but to the best of our knowledge, 'NASPOT 11' represents the first sweetpotato cultivar bred from segregating populations by participatory plant breeding (PPB) for Africa and perhaps the world (Gibson et al., 2008; Mwanga et al., 2010). 'NASPOT 11' has acceptable storage root shape (long elliptic) when grown in light soils, has high dry matter $(\mathrm{DM})(\approx 34 \%)$, and good to excellent consumer acceptance, depending on growth conditions. The cultivar has moderate to high field resistance to sweetpotato virus disease (SPVD) and Alternaria bataticola blight.

\footnotetext{
Received for publication 23 Aug. 2010. Accepted for publication 21 Nov. 2010.

This work was supported, in part, by a grant from The McKnight Foundation, Collaborative Crop Research Program, the UK Department for International Development (DFID), and the Biological and Biotechnology Science Research Council (BBSRC) through their Sustainable Agricultural Research for Development (SARID) program project BB/F004028/1.

${ }^{1}$ Former Team Leader, Sweetpotato Research, NARO; currently sweetpotato breeder, Sub-Saharan Africa, International Potato Center (CIP), Naguru Hill, Katalima Road, Plot 106, Box 2274, Kampala, Uganda.

${ }^{2}$ To whom reprint requests should be addressed; e-mail r.mwanga@cgiar.org; rmwanga7@gmail.com.
}

Both diseases can be devastating, causing high storage root yield losses (50\% to $90 \%)$ in susceptible clones (Gibson et al., 1998; Loebenstein et al., 2009; Osiru et al., 2009). Therefore, in terms of resistance to diseases, 'NASPOT 11 ' is superior to other previously released cultivars (Tables 1 through 3 ). Storage root yields exceeded $10 \mathrm{t} \cdot \mathrm{ha}^{-1}$ on-farm under good growing conditions (Tables 2 and 3 ) compared with the average national storage root yield of $4.0 \mathrm{t} \cdot \mathrm{ha}^{-1}$ (International Potato Center, 1999). Here we report the release of 'NASPOT 11', which provides consumers and farmers with a new cultivar to contribute to food security in the farming and food systems of Uganda.

\section{Origin}

During sweetpotato PPB trials on-farm (Gibson et al., 2008) and in on-station evaluations in major selected agroecologies in Uganda (Mwanga et al., 2010), 'NASPOT 11 ' was coded as NIS/2003/NKA1081L, in which NIS = Namulonge Ipomoea selection, $2003=$ the initial year the clone was selected, NKA $=$ New Kawogo, the female parent, $1081=$ the selection (genotype) number, and $\mathrm{L}=$ Luwero District, the district where the farmer group initially selected the seedling selection by farmers in the PPB trials from bulked seed obtained from an open-pollinated polycross nursery of 24 parents grown between 2000 and 2001. The 24 parents consisted of 10 released cultivars, three introductions, five advanced clones from the Ugandan sweetpotato breeding program, and six landrace cultivars described in detail by Mwanga et al. (2009). These 24 parents were for improveand cloned it. 'NASPOT 11' is a seedling ment or as sources of one or a combination of genes for control of desirable traits such as high DM (30\% or greater), resistance to SPVD and Alternaria stem blight (Alternaria bataticola), and earliness (3 to 4 months). 'NASPOT 11' is a progeny of 'New Kawogo' as the female parent from open-pollinated seed; thus, its male pedigree is unknown.

\section{Description and Performance}

Selected descriptors of the International Potato Center (CIP), Asian Vegetable Research and Development Center, and International Board for Plant Genetic Resources (1991) were used to describe 'NASPOT 11'. The main descriptors and gross morphology (in parentheses) of 'NASPOT 11' are as follows: 1) plant type (semierect); 2) predominant vine pigmentation (green); 3) secondary color vine pigmentation (purple nodes); 4) mature leaf shape general outline (triangular); 5) lobe type (no lateral lobes); 6) mature leaf size (small, less than $8.0 \mathrm{~cm}$ ); 7) mature leaf color (green); 8) vein color (all veins mostly or totally purple); 9) immature leaf color (purple on both surfaces); 10) petiole pigmentation (green with purple spots throughout petiole); 11) flowering habit (sparse); 12) stigma exertion (inserted); 13) seed capsule set (sparse); 14) storage root formation (dispersed); 15) storage root shape (long elliptic); 16) storage root skin color (intermediate purple-red, no secondary color); and 17) root flesh color (cream, no secondary color) (Fig. 1). Data and detailed information on 'NASPOT 11' officially released in Uganda in April 2010 are described by Mwanga et al. (2010). The release information included detailed descriptions of test sites, materials and methods, cultivars, pedigree, PPB procedure, planting materials, on-station and on-farm trials, planting and harvesting dates, pest and disease evaluation protocols, farmer selection criteria, acceptability assessment, experimental designs, stability analysis, dry matter estimation, production package, and cultivar maintenance.

In 2003, sweetpotato PPB was initiated with three farmer groups in Luwero, Mpigi, and Kiboga Districts in Central Uganda to assess the benefits of PPB (Gibson et al., 2008). This includes the time it would take to deliver improved cultivars to farmers and to determine the advantages of PPB. Each group received 2000 to 6000 pre-germinated sweetpotato seeds of at least two families (New Kawogo and Bunduguza) depending on the availability of scientific staff, technicians, and willingness of the groups to handle segregating populations from the seedling nursery and subsequent large numbers of clones in the initial stages of the PPB trials. Each selected seedling, based on vigor, root flesh color, and absence of disease symptoms, furnished five vine cuttings that were planted at each of the six sites on ridges, $1 \mathrm{~m}$ apart, and $30 \mathrm{~cm}$ between the plants. Subsequent clonal selections based on additional desirable traits such as high DM and storage root shape were planted on mounds or ridges in 2004 onward. 
By 2005 onward, the remaining selected clones were planted on at least three farms at each site. During clonal evaluation, 2005 to 2008, the farmers and researchers evaluated the selected clones in PPB trials in the three districts Luwero, Mpigi, and Kiboga. In Luwero, nine farmers each hosted the trials. Each farm consisted of a household that planted one to three ridges ( 50 plants per ridge), $1 \mathrm{~m}$ between ridges, $30 \mathrm{~cm}$ between plants on the ridge, with Dimbuka and NASPOT 1 as control cultivars. At harvest, 5 months after planting, taste ranking was done by 12 farmers (eight females, four males) in which $1=$ best (most preferred) and $9=$ least preferred, based on pairwise selection of the nine clones. In Mpigi, 15 farmers (farms) each hosted the PPB trial (13 females, two males) who planted four ridges (30 plants per ridge), $1 \mathrm{~m}$ between ridges, $30 \mathrm{~cm}$ between plants on the ridge. Taste ranking was done by 15 farmers (12 females, three males): 1 = best (most preferred) and $11=$ least preferred as described previously. In Kiboga, one farmer hosted the PPB trial but a group of nine farmers (eight females, one male) were involved, planting the on-farm trial in three replications, on mounds (three plants per mound), $1 \mathrm{~m}$ between centers of the mound.

The promising advanced clones in the PPB trials were evaluated on-station at Namulonge, Kachwekano, Ngetta, and Serere and on-farm in Soroti and and Kabale Districts between 2006/2007 and 2008/2009. The routine procedure of the National Sweetpotato Program for evaluating advanced sweetpotato clones was followed (Mwanga et al., 2009). The clones were planted on four ridges, $5.4 \mathrm{~m}$ long, $1 \mathrm{~m}$ between ridges, one vine cutting per planting point on the ridge, $0.3 \mathrm{~m}$ between plants (18 plants/ridge) (plant density, $\approx 33,330$ plants/ha), in a randomized complete block design (RCBD) with four replications. All outside rows of the experimental plots had border plants to minimize experimental error resulting from competition by border plants in adjacent plots. SPVD and $A$. bataticola blight were scored at 2 months after planting, whereas vine and total root and biomass yield were computed from plot yields. DM of storage roots was expressed as the average percentage of dry weight of fresh weight. DM was determined after weighing two replications of 500 -g samples of sliced roots and oven-drying to a constant weight at $65^{\circ} \mathrm{C}$.

The PPB trials on-farm and on-station comprised three broad agroecologies: 1) the warm, sub-humid short grasslands (Ngetta and Serere stations; Lira and Soroti Districts) where sweetpotato weevils and drought are significant; 2) the warm, moist, tall grasslands (Namulonge station; Luwero, Mpigi, and Kiboga Districts) where SPVD is prevalent and severe; and 3) the cool, moist, southwestern highlands (Kachwekano station; Kabale District) characterized by Alternaria stem blight and low soil fertility stresses. In the trials, 'NASPOT 11' was evaluated to confirm resistance to SPVD, Alternaria stem blight, and sweetpotato weevils, Cylas puncticollis (Boheman) and C. brunneus (Fabricius)
Table 1. Yield, storage root quality characteristics, and disease and insect pest reaction of the local control and 'NASPOT 11' released in April 2010 in Uganda.

\begin{tabular}{|c|c|c|}
\hline Attribute & NASPOT 11 & $\begin{array}{l}\text { Dimbuka-Bukulula } \\
\text { (local control) }\end{array}$ \\
\hline$\overline{\text { Dry matter percent (range) }}$ & $33.5(29.6-36.0)$ & $32.4(26.9-35.9)$ \\
\hline Cooked texture & Somewhat dry & Somewhat dry \\
\hline Sweetness & Moderate & Moderate \\
\hline Field reaction to weevils ${ }^{z}$ & $\mathrm{~S}$ & $\mathrm{~S}$ \\
\hline Field reaction to $\mathrm{SPVD}^{\mathrm{z}, \mathrm{y}}$ & MR & $\mathrm{S}$ \\
\hline Field reaction to & & \\
\hline Alternaria stem blight ${ }^{2}$ & HR & MR \\
\hline Maturity (days) & 115 & 128 \\
\hline $\begin{array}{l}\text { Mean and }\left(\text { range }^{\mathrm{x}}\right) \text { of } \\
\text { storage root yields in } \\
\text { various yield trials }\left(\mathrm{t} \cdot \mathrm{ha}^{-1}\right)\end{array}$ & $26.5(3.7-48.2)$ & $23.3(3.6-34.8)$ \\
\hline $\begin{array}{l}\text { Mean storage root yield } \\
\text { (\% of local control) }\end{array}$ & 116 & 100 \\
\hline
\end{tabular}

${ }^{2}$ Susceptible $(\mathrm{S})=$ considerable damage or numbers present to severe damage or very high numbers present, respectively; moderately resistant $(\mathrm{MR})=$ moderate damage; highly resistant $(\mathrm{HR})=$ little or no apparent damage.

${ }^{\mathrm{y}} \mathrm{SPVD}=$ sweetpotato virus disease.

${ }^{\mathrm{x}}$ The wide variation in storage root yield is resulting from variation in environmental factors such as erratic rain and amount of rainfall during the growing season and differences in farm management and soil types in the different agroecologies.

Table 2. Performance of 'NASPOT 11' in on-farm sweepotato participatory breeding trials, 2005-2008, in Uganda.

\begin{tabular}{|c|c|c|c|c|c|c|}
\hline \multirow[b]{2}{*}{ District ${ }^{2} /$ year } & \multirow[b]{2}{*}{ Clone } & \multicolumn{2}{|c|}{ Yield $^{y}\left(\mathrm{t} \cdot \mathrm{ha}^{-1}\right)$} & \multicolumn{2}{|c|}{ Disease severity $^{\mathrm{x}}$} & \multirow{2}{*}{$\begin{array}{c}\text { Taste test rank }{ }^{\mathrm{w}} \\
(\mathrm{n}=17 ; \mathrm{m}=7, \mathrm{f}=10\end{array}$} \\
\hline & & Root & $\overline{\text { Biomass }}$ & $\overline{\text { SPVD }}$ & Alternaria & \\
\hline \multirow[t]{14}{*}{ Mpigi 2005} & NKA259L & 18.0 & 37.2 & 3.0 & 2.0 & 5 \\
\hline & NKA103M & 17.6 & 60.1 & 2.3 & 1.7 & 2 \\
\hline & NKA102M & 19.5 & 54.5 & 3.0 & 2.0 & 8 \\
\hline & NKA41M & 17.4 & 58.1 & 3.0 & 3.0 & 1 \\
\hline & WAG34L & 13.8 & 63.7 & 2.3 & 2.0 & 7 \\
\hline & NASPOT 11 & 27.8 & 77.3 & 2.3 & 2.0 & 3 \\
\hline & BND145M & 3.8 & 13.3 & 3.0 & 5.0 & 4 \\
\hline & NKA318L & 30.1 & 53.6 & 2.3 & 2.3 & 3 \\
\hline & Dimbuka & 4.9 & 46.4 & 3.7 & 2.0 & 7 \\
\hline & BND145L & 18.1 & 45.8 & 2.3 & 2.7 & 6 \\
\hline & NKA51M & 5.8 & 17.9 & 2.7 & 2.0 & 4 \\
\hline & Mean & 16.1 & 48.0 & 2.7 & 2.4 & NA \\
\hline & $\operatorname{LSD}_{0.05}$ & 7.8 & 20.6 & 0.8 & 0.7 & NA \\
\hline & CV $(\%)$ & 28.5 & 25.2 & 17.4 & 17.9 & NA \\
\hline
\end{tabular}

Luwero 2005

$\begin{array}{lrrrrc} & & & & (\mathrm{n}=12 ; \mathrm{m}=4, \mathrm{f}=12) \\ \text { NKA259L } & 17.2 & 31.9 & 1.7 & 1.3 & 3 \\ \text { NASPOT 11 } & 12.2 & 30.2 & 1.3 & 1.3 & 6 \\ \text { NKA147M } & 11.9 & 21.8 & 1.3 & 2.7 & 7 \\ \text { NKA318L } & 16.1 & 28.9 & 1.7 & 1.7 & 2 \\ \text { NKA103M } & 10.7 & 24.7 & 1.3 & 1.3 & 5 \\ \text { NKA102M } & 9.4 & 28.6 & 1.3 & 1.3 & 9 \\ \text { BND145L } & 17.6 & 33.8 & 1.3 & 1.3 & 8 \\ \text { Dimbuka } & 17.9 & 44.5 & 1.7 & 2.0 & 4 \\ \text { NASPOT 1 } & 16.7 & 32.2 & 1.3 & 1.3 & \text { NA } \\ \text { Mean } & 14.4 & 30.7 & 1.5 & 1.6 & \text { NA } \\ \text { LSD } & 6.3 & 10.0 & 0.5 & 1.3 & \text { NA } \\ \text { CV }(\%) & 25.4 & 18.8 & 21.0 & 27.1 & \end{array}$

Luwero 2006

CV $(\%) \quad 25.4 \quad 18.8$

$21.0-27.1$

$\begin{array}{llllll}\text { NK259L } & 10.4 & 18.8 & 1.9 & 1.2 & \text { NA }\end{array}$

$\begin{array}{llllll}\mathrm{NK} 103 \mathrm{M} & 12.5 & 24.2 & 1.4 & 1.1 & \text { NA }\end{array}$

$\begin{array}{lrrrrr}\text { NK102M } & 6.7 & 23.0 & 1.6 & 1.6 & \text { NA }\end{array}$

$\begin{array}{lrrrrr}\text { NASPOT } 1 & 12.4 & 28.9 & 1.9 & 2.6 & \text { NA }\end{array}$

$\begin{array}{lrrrrr}\text { DIMBUKA } & 6.6 & 29.8 & 1.5 & 1.3 & \text { NA }\end{array}$

$\begin{array}{llllll}\text { NASPOT } 11 & 13.3 & 30.8 & 1.3 & 1.1 & \text { NA }\end{array}$

$\begin{array}{llllll}\text { NK318L } & 11.3 & 18.1 & 1.8 & 1.2 & \text { NA }\end{array}$

$\begin{array}{lrrrrr}\text { Mean } & 10.5 & 24.8 & 1.7 & 1.4 & \text { NA }\end{array}$

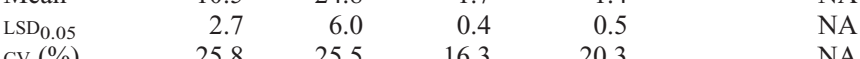

$\begin{array}{llllll}\text { CV }(\%) & 25.8 & 25.5 & 16.3 & 20.3 & \text { NA }\end{array}$

Mpigi 2006

\begin{tabular}{llllll} 
NKA103M & 6.5 & 12.3 & 1.0 & 1.7 & NA \\
BND145L & 4.7 & 12.6 & 1.3 & 2.3 & NA \\
WAG34M & 4.9 & 11.9 & 1.0 & 2.0 & NA \\
\hline
\end{tabular}

(Continued on next page) 
Table 2. (Continued) Performance of 'NASPOT 11' in on-farm sweepotato participatory breeding trials, 2005-2008, in Uganda.

\begin{tabular}{|c|c|c|c|c|c|c|}
\hline \multirow[b]{2}{*}{ District $^{2} /$ year } & \multirow[b]{2}{*}{ Clone } & \multicolumn{2}{|c|}{ Yield $^{y}\left(t \cdot h a^{-1}\right)$} & \multicolumn{2}{|c|}{ Disease severity ${ }^{x}$} & \multirow{2}{*}{$\begin{array}{c}\text { Taste test rank }{ }^{\mathrm{w}} \\
(\mathrm{n}=17 ; \mathrm{m}=7, \mathrm{f}=10)\end{array}$} \\
\hline & & $\overline{\text { Root }}$ & Biomass & $\overline{\text { SPVD }}$ & $\overline{\text { Alternaria }}$ & \\
\hline & NKA 318L & 5.2 & 10.1 & 1.3 & 2.3 & NA \\
\hline & NASPOT 11 & 5.1 & 12.2 & 1.7 & 2.0 & NA \\
\hline & NKA 259L & 8.5 & 12.4 & 1.7 & 2.0 & NA \\
\hline & NKA $102 \mathrm{M}$ & 4.0 & 9.6 & 2.0 & 2.0 & NA \\
\hline & Local control & 3.6 & 9.1 & 1.8 & 2.0 & NA \\
\hline & Mean & 5.3 & 11.3 & 1.5 & 2.0 & NA \\
\hline & $\mathrm{LSD}_{0.05}$ & 4.5 & NS & NS & NS & NA \\
\hline & CV $(\%)$ & 21.5 & 19.1 & 27.5 & 18.1 & NA \\
\hline \multirow[t]{14}{*}{ Soroti 2007} & & & & & & $(\mathrm{n}=24 ; \mathrm{m}=14, \mathrm{f}=10)$ \\
\hline & NKA259L & 2.7 & 6.6 & 1.2 & 1.0 & 10 \\
\hline & NKA103M & 3.8 & 7.8 & 1.0 & 1.0 & 3 \\
\hline & NASPOT 11 & 3.7 & 7.2 & 1.0 & 1.0 & 1 \\
\hline & NKA318 L & 2.9 & 6.7 & 1.2 & 1.2 & 8 \\
\hline & NASPOT 1 & 4.0 & 7.5 & 1.0 & 1.0 & 4 \\
\hline & Dimbuka & 3.2 & 6.9 & 1.0 & 1.0 & 7 \\
\hline & BND12K & 2.5 & 8.3 & 1.0 & 1.0 & 5 \\
\hline & NKA14K & 2.5 & 5.5 & 1.0 & 1.0 & 9 \\
\hline & BND21K & 1.4 & 5.0 & 1.0 & 1.2 & 2 \\
\hline & BND18K & 2.5 & 6.9 & 1.0 & 1.0 & 6 \\
\hline & Mean & 3.1 & 6.8 & 1.1 & 1.0 & NA \\
\hline & $\operatorname{LSD}_{0.05}$ & 1.2 & 2.4 & 0.3 & 0.3 & NA \\
\hline & CV $(\%)$ & 29.6 & 27.0 & 22.7 & 19.5 & NA \\
\hline \multirow[t]{14}{*}{ Kiboga 2007} & & & & & & $(\mathrm{n}=20 ; \mathrm{m}=8 ; \mathrm{f}=12)$ \\
\hline & NKA259L & 7.0 & 15.9 & 2.0 & 2.0 & 5 \\
\hline & NKA103M & 11.4 & 20.0 & 2.0 & 2.0 & 7 \\
\hline & NASPOT 11 & 11.8 & 21.7 & 2.0 & 1.8 & 1 \\
\hline & NKA318 L & 3.6 & 12.5 & 2.0 & 2.0 & 6 \\
\hline & NASPOT 1 & 11.7 & 21.1 & 1.8 & 2.0 & 3 \\
\hline & Dimbuka & 12.6 & 21.6 & 2.3 & 2.0 & 6 \\
\hline & BND12K & 9.3 & 20.3 & 1.8 & 1.5 & 2 \\
\hline & NKA14K & 11.9 & 27.3 & 2.0 & 2.0 & 4 \\
\hline & BND21K & 13.9 & 27.7 & 2.3 & 2.0 & 8 \\
\hline & BND18K & 10.2 & 35.9 & 2.0 & 1.5 & 7 \\
\hline & Mean & 11.1 & 22.4 & 2.0 & 1.9 & NA \\
\hline & $\operatorname{LSD}_{0.05}$ & 4.1 & 8.3 & 0.5 & 0.6 & NA \\
\hline & CV $(\%)$ & 25.4 & 25.5 & 16.1 & 21.7 & NA \\
\hline \multicolumn{7}{|l|}{ Kabale 2008} \\
\hline & NKA259L & 9.2 & 28.3 & 2.0 & 2.4 & NA \\
\hline & NKA103M & 10.3 & 23.7 & 2.2 & 2.2 & NA \\
\hline & NASPOT 11 & 16.6 & 29.3 & 2.2 & 1.7 & NA \\
\hline & NKA318L & 11.2 & 33.8 & 2.0 & 1.9 & NA \\
\hline & NKA102M & 9.8 & 41.7 & 2.0 & 2.3 & NA \\
\hline & Dimbuka & 12.0 & 26.2 & 2.0 & 2.1 & NA \\
\hline & BND145M & 10.1 & 31.6 & 2.1 & 2.8 & NA \\
\hline & NKA41M & 12.0 & 24.0 & 2.1 & 3.6 & NA \\
\hline & WAG34L & 8.0 & 25.2 & 2.0 & 2.5 & NA \\
\hline & BND145L & 7.3 & 17.8 & 2.3 & 2.3 & NA \\
\hline & Mean & 10.7 & 28.2 & 2.1 & 2.4 & NA \\
\hline & $\operatorname{LSD}_{0.05}$ & 2.5 & 4.6 & NS & 0.6 & NA \\
\hline & CV $(\%)$ & 27.5 & 28.8 & 15.0 & 31.7 & NA \\
\hline
\end{tabular}

${ }^{2}$ Luwero, Mpigi, and Kiboga Districts represent the warm, moist tall grasslands; Soroti, the warm subhumid short grasslands; and Kabale, the cool moist southwest highlands.

${ }^{y}$ Storage root yields were assessed on 10 to 15 farms per district, gross plot was $30 \mathrm{~m}^{2}$ ( 30 mounds), net plot harvested was $12 \mathrm{~m}^{2}$ (12 mounds of 36 plants); each farm in a district was considered a replicate. Biomass = storage root yield plus vine yield. $\mathrm{NS}=$ non-significant.

${ }^{\mathrm{SPVD}}=$ sweetpotato virus disease and Alternaria blight severity in field testing; rating scale: $1=$ no symptoms; 2 = mild symptoms; $3=$ moderate symptoms; $4=$ severe symptoms; and $5=$ very severe symptoms.

wTaste test rank was based on the aggregate pairwise comparison of the panel of farmers; $n=$ number of farmers in the tasting panel, $\mathrm{m}=$ male, $\mathrm{f}=$ female; $1=$ most preferred, $11=$ least preferred; $\mathrm{NA}=$ not applicable.

$\mathrm{LSD}=$ least significant difference.

(Tables 1 through 3). Categories of the resistance to disease and weevil damage were based on field tests under natural disease inoculum and weevil population pressures as described by Mwanga et al. (2002, 2009). Disease infection and pest attack on-farm and on-station varied from low to high in the yield of 'NASPOT 11' varied across sites in the different agroecologies in PPB trials onfarm and on-station (Tables 2 and 3), but they were above the national average of $4.0 \mathrm{t} \cdot \mathrm{ha}^{-1}$ and the local checks. On average 'NASPOT 11 ' had better storage root yield and stability parameter estimates, namely regression coefficient $(b)$, deviation from regression $\left(S^{2} d\right)$, and Tai's test stability criteria ( $\alpha$ and $\lambda$ ) (Tai, 1971) compared with the local checks Magabari, New Kawogo, and Dimbuka (Table 4). A cultivar is considered to have stable performance if the slope of the regression line is close to 1 and the deviations from the regression line (mean square deviations) are small. In Tai's (1971) stability analysis, the interaction term is partitioned into two components: the linear response to environmental effects, which is measured by a statistic $\alpha$, and the deviation from the linear response, measured by another statistic $\lambda$. A perfectly stable cultivar has $(\alpha, \lambda)=(-1,1)$ and a cultivar with average stability is expected to have $(\alpha, \lambda)=$ $(0,1)$. Tai's analysis also provides a method of obtaining the prediction interval for $\alpha=0$ and a confidence interval for $\lambda$ values. Although on average the root yields of 'NASPOT 11' were similar to the yields of 'NASPOT 1' released in 1999, the former was more reliable based on stability estimates (Table 4), and higher resistance to SPVD and Alternaria blight (Table 3).

From the on-farm and on-station trial results (Tables 2 and 3), 'NASPOT 11' was as good as or better in performance for the desired traits than the local checks in specific locations and in the four agroeclogies represented by the four research stations. The taste ranking varied with location and community, suggesting that although 'NASPOT 11' in general performed well, it had superior performance where it was more specifically adapted such as in Kabale (Table 2) and at Namulonge (Table 3). These PPB trials demonstrate the potential for significant rapid progress in sweetpotato breeding, especially in specific environments, with the PPB approach complementing conventional sweetpotato breeding (Ashby, 2009). In the third year (2005) of clonal selection, participating farmers had started consuming storage roots from the promising PPB sweetpotato materials in their homes. In the fourth year (2006), PPB participating farmers started selling 'NASPOT 11' in their local markets in Zirobwe, Luwero District. This is a big plus for the PPB approach in ensuring that cultivars identified are well adapted to specific conditions and are highly client-oriented. Other PPB clonal selections had negative traits such as poor storage root shape, so they could not be sold in local markets. These results demonstrate the value of PPB and are in agreement with Belay et al. (2008), Gabriel et al. (2000), Gibson et al. (2008), Ssemakula et al. (2003), Thiele et al. (2001), and Witcombe et al. (2003). Sweetpotato consumption and exchange by participating farmers [participatory variety selection (PVS)] in the so-called conventional breeding would normally start only in Year 6 or 7 (Mwanga et al., 2009). 


\begin{tabular}{|c|c|c|c|c|c|c|c|c|c|c|c|}
\hline \multirow[b]{3}{*}{ Name of clone } & \multirow{2}{*}{\multicolumn{4}{|c|}{ Site $^{\mathrm{z}}$}} & \multicolumn{3}{|c|}{ Mean across sites } & \multirow{3}{*}{$\begin{array}{l}\mathrm{SPVD}^{\mathrm{w}} \text { at } \\
\text { Namulonge }\end{array}$} & \multirow{3}{*}{$\begin{array}{l}\text { Alternaria } \\
\text { at Kachwekano }\end{array}$} & \multirow{2}{*}{\multicolumn{2}{|c|}{ Storage root color }} \\
\hline & & & & & \multirow{2}{*}{$\begin{array}{l}\text { Root } \\
\text { yield } \\
\left(\mathrm{t} \cdot \mathrm{ha}^{-1}\right)\end{array}$} & \multirow{2}{*}{$\begin{array}{l}\text { Biomass } \\
\left(\mathrm{t} \cdot \mathrm{ha}^{-1}\right)\end{array}$} & \multirow{2}{*}{$\begin{array}{l}\text { Dry matter } \\
(\%)\end{array}$} & & & & \\
\hline & \multicolumn{4}{|c|}{ Storage root yield ${ }^{\mathrm{y}}\left(\mathrm{t} \cdot \mathrm{ha}^{-1}\right)$} & & & & & & Skin & Flesh \\
\hline NASPOT 1 & 45.9 & 43.5 & 15.9 & 50.7 & 39.0 & 74.5 & 32.8 & 2.5 & 2.1 & Cream & Cream \\
\hline NKA103M & 43.5 & 36.1 & 11.4 & 44.3 & 33.8 & 58.0 & 32.8 & 1.9 & 1.5 & Purple-red & Cream \\
\hline Dimbuka & 36.1 & 40.6 & 11.3 & 40.6 & 32.1 & 61.4 & 32.6 & 2.5 & 2.3 & Cream & Cream \\
\hline NKA259L & 44.7 & 38.1 & 12.6 & 31.7 & 31.8 & 57.3 & 33.6 & 2.6 & 1.5 & Purple-red & Cream \\
\hline NKA318 L & 31.7 & 37.1 & 4.7 & 31.6 & 26.3 & 54.3 & 32.3 & 2.0 & 1.1 & Purple-red & Cream \\
\hline New Kawogo & 33.3 & 31.8 & 2.3 & 21.9 & 22.3 & 66.7 & 30.9 & 2.3 & 3.1 & Purple-red & Cream \\
\hline Magabari & 20.4 & 29.6 & 5.4 & 21.0 & 19.1 & 57.3 & 33.3 & 2.8 & 1.3 & Cream & Cream \\
\hline Mean & 38.8 & 35.9 & 9.6 & 35.6 & 30.0 & 61.8 & 32.5 & 2.2 & 1.8 & NA & NA \\
\hline $\mathrm{LSD}_{0.05}$ & 8.4 & 9.0 & 2.5 & 9.6 & 3.9 & 6.9 & NA & 0.4 & 0.5 & NA & NA \\
\hline CV $(\%)$ & 21.7 & 25.1 & 26.4 & 26.9 & 26.4 & 22.8 & NA & 18.9 & 30.8 & NA & NA \\
\hline
\end{tabular}

${ }^{2}$ Sites: Namulonge represents the warm, moist, tall grasslands in the high SPVD pressure agroecology; Ngetta and Serere represent the warm, sub-humid short grasslands with high weevil populations during dry periods; and Kachwekano represents the cool, moist, southwestern highlands with high Alternaria blight pressure.

${ }^{\mathrm{y}}$ Mean of four replications.

${ }^{\mathrm{x}}$ Dry matter $=$ percent dry matter of storage roots; NA = not applicable, statistical analysis not done.

${ }^{\mathrm{w}} \mathrm{SPVD}=$ sweetpotato virus disease and Alternaria blight severity rating scale: $1=$ no symptoms; $2=$ mild symptoms; $3=$ moderate symptoms; $4=$ severe symptoms; and $5=$ very severe symptoms.

LSD $=$ least significant difference.
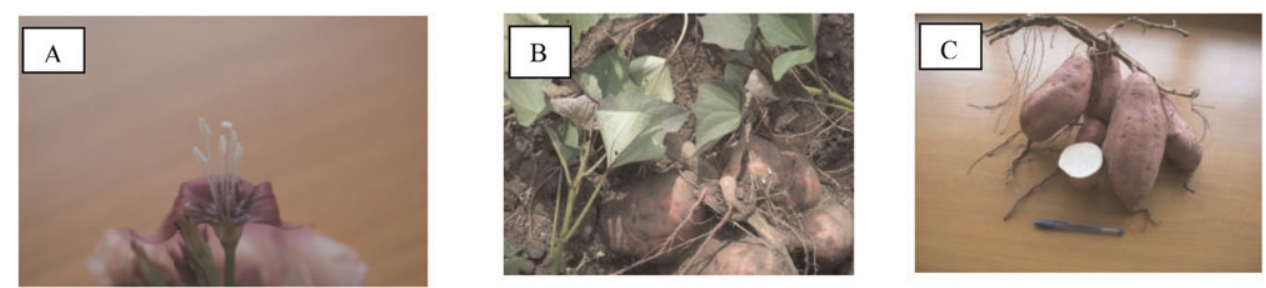

Fig. 1. Morphological characters of 'NASPOT 11', (A) flower, (B) shoot and storage roots, and (C) storage root attachment, shape, and flesh color.

Table 4. Average storage root yield and estimates of stability parameters by regression analysis and Tai stability test for 10 sweetpotato clones during two seasons, 2006/2007 to 2008/2009 in four sites, Namulonge, Kachwekano, Ngetta, and Serere in Uganda.

\begin{tabular}{|c|c|c|c|c|c|c|c|c|c|}
\hline \multirow[b]{2}{*}{ Clone } & \multirow{2}{*}{$\begin{array}{l}\text { Root yield } \\
\left(\mathrm{t} \cdot \mathrm{ha}^{-1}\right)\end{array}$} & \multicolumn{4}{|c|}{ Regression analysis ${ }^{z}$} & \multicolumn{4}{|c|}{ Tai test ${ }^{y}$} \\
\hline & & $b$ & Prob. & $S^{2} d$ & Prob. & $\alpha$ & Prob. & $\lambda$ & Prob. \\
\hline NASPOT 11 & 39.7 & 0.92939 & $<0.0001$ & 132.6 & 0.4217 & 0.37075 & 0.44939 & 1.22 & 0.29967 \\
\hline NASPOT 1 & 39.0 & 0.92925 & $<0.0001$ & 135.6 & $<0.0001$ & 0.83026 & 0.42073 & 1.07 & 0.34724 \\
\hline NKA103M & 33.8 & 0.72538 & $<0.0001$ & 172.4 & $<0.0001$ & 0.62614 & 0.81173 & 3.97 & 0.02157 \\
\hline Dimbuka & 32.1 & 0.77436 & 0.0001 & 151.8 & 0.0001 & 0.67518 & 0.6496 & 2.55 & 0.08307 \\
\hline NKA259L & 31.8 & 0.72542 & $<0.0001$ & 196.2 & $<0.0001$ & 0.62618 & 0.96523 & 5.62 & 0.00476 \\
\hline BND145L & 28.1 & 0.65488 & 0.0031 & 140.4 & 0.0031 & 0.55556 & 0.53942 & 1.76 & 0.17766 \\
\hline NKA102M & 7.6 & 0.81296 & $<0.0001$ & 172.4 & $<0.0001$ & 0.71383 & 0.48613 & 1.43 & 0.24474 \\
\hline NK318 L & 26.3 & 0.72548 & $<0.0001$ & 222.2 & $<0.0001$ & 0.62624 & 1.10897 & 7.42 & 0.00096 \\
\hline New Kawogo & 22.3 & 0.92077 & $<0.0001$ & 241.9 & $<0.0001$ & 0.82177 & 1.20676 & 8.79 & 0.00029 \\
\hline Magabari & 19.1 & 0.1703 & $<0.0001$ & 130.4 & $<0.0001$ & 0.07039 & 0.44939 & 1.22 & 0.29967 \\
\hline
\end{tabular}

${ }^{2}$ Eberhart and Russel (1966) stability criteria: $b=1.0$ and $S^{2} d=0$ at $5 \%$ of probability ( $b$ value in column corresponds to the regression coefficient of the i-th cultivar, $S^{2} d$ value in column corresponds to the deviation from regression of the i-th cultivar on the environmental indices). A cultivar is considered to have stable performance if the slope of the regression line is close to 1 and the deviations from the regression line (mean square deviations) are small.

'Tai's test stability criteria (Tai, 1971): $\alpha=0$ and $\lambda=1.0$ at $5 \%$ probability $(\alpha$, lower prediction value $=$ $0.26193), \lambda$, upper confidence interval value $=3.8178 ; \alpha$ value in column corresponds to the linear response of the $i$-th cultivar on the environmental effects, $\lambda$ value in the column corresponds to deviation from the linear response of the error variance). In Tai's (1971) stability analysis, the interaction term is partitioned into two components: the linear response to environmental effects, which is measured by a statistic $\alpha$, and the deviation from the linear response, measured by the statistic $\lambda$. A perfectly stable cultivar has $(\alpha, \lambda)=(-1,1)$ and a cultivar with average stability is expected to have $(\alpha, \lambda)=(0,1)$. Tai's analysis also provides a method of obtaining the prediction interval for $\alpha=0$ and a confidence interval for $\lambda$ values.

\section{Insect and Disease Resistance}

'NASPOT 11' is susceptible to sweetpotato weevils in no-choice laboratory tests and during field evaluation in dry seasons although its storage roots are mostly produced at moderate depth where they are protected from attack. The cultivar has moderate field resistance to SPVD under Namulonge conditions where SPVD inoculum pressure is high and high field resistance to Alternaria stem blight at Kachwekano where high $A$. bataticola blight pressure is prevalent. Both SPVD and $A$. bataticola blight are devastating to susceptible clones. 'NASPOT 11 ' is expected to perform well in agroecologies with low to high SPVD and low to high Alternaria blight pressure with welldistributed rainfall for at least 3 months from planting and during the early growth cycle. 'NASPOT 11' is expected to be a source parent for resistance to SPVD and A. bataticola blight in sweetpotato breeding schemes.

\section{Diffusion of 'NASPOT 11'}

'NASPOT 11 ' is currently grown in the areas where PPB trials were conducted and where participatory trial evaluations on-farm were conducted together with on-station trials to generate stability performance data in Luwero, Mpigi, Soroti, Kiboga, Kabale, and Lira Districts. The spread of the cultivar is mainly through farmer-to-farmer exchange or sale of planting materials. In the absence of special promotions by development agents, its spread is expected to increase faster compared with other sweetpotato cultivars tha are not orange-fleshed (Mwanga et al., 2009).

\section{Availability}

'NASPOT 11' is maintained as pathogentested plants in a screenhouse at the Quarantine 
Station, Muguga, in Kenya as well as in the field and screenhouse by NaCRRI in Uganda. Requests for this cultivar should be addressed to: Seed Unit, CIP, P.O. Box 25171, Nairobi, Kenya. Requests for planting material within Uganda should be directed to: Sweetpotato Program, NaCRRI, P.O. Box 7084, Kampala.

\section{Literature Cited}

Ashby, J.A. 2009. The impact of participatory plant breeding. In: Ceccarelli, S., E.P. Guimarães, and E. Weltzien (eds.). Plant breeding and farmer participation. Food and Agriculture Organization of the United Nations, Rome, Italy.

Belay, G., H. Tefera, A. Getachew, K. Assefa, and G. Metaferia. 2008. Highly client-oriented breeding with farmer participation in the Ethiopian cereal tef [Eragrostis tef (Zucc.) Trotter]. Afri. J. Agr. Res. 3:22-28.

Eberhart, S and W. Russel. 1996. Stability analysis and its application to potato regional trials. Crop Sci. 6:36-40.

Gabriel, J., R. Torrez, and G. Thiele. 2000. Participatory approaches in potato improvement: Experience of PROINPA in Bolivia, p. 194 199. In: Almekinders, C.J.M. and W. de Boef (eds.). Encouraging diversity. The conservation and development of plant genetic resources. Intermediate Technology Publications, London, UK.

Gibson, R.W., E. Byamukama, I. Mpembe, J. Kayongo, and R.O.M. Mwanga. 2008. Work- ing with farmer groups in Uganda to develop new sweet potato cultivars: Decentralisation and building on traditional approaches. Euphytica 159:217-228.

Gibson, R.W., I. Mpembe, T. Alicai, E.E. Carey, R.O.M. Mwanga, S.E. Seal, and H.J. Vetten. 1998. Symptoms, etiology and serological analysis of sweetpotato virus disease in Uganda. Plant Pathol. 47:95-102.

International Potato Center. 1999. CIP sweetpotato facts: Production, consumption, feed use. CIP, Lima, Peru. July 2010. <http://www.cipotato. org/sweetpotato/ facts/ $>$.

International Potato Center, Asian Vegetable Research and Development Center, and the International Board for Plant Genetic Resources. 1991. Descriptors for sweetpotato. In: Huaman, Z. (ed.). Intl. Board for Plant Genetic Resources, Rome, Italy.

Loebenstein, G., G. Tottappilly, S. Fuentes, and J. Cohen. 2009. Virus and phytoplasma diseases. In: Loebenstein, G. and G. Thottappilly (eds.). The sweetpotato. Springer, Berlin, Germany.

Mwanga, R.O.M., B. Kigozi, J. Namakula, I. Mpembe, C. Niringiye, S. Tumwegamire, R Gibson, and C. Yencho. 2010. Submission to the Variety Release Committee for release of sweetpotato varieties. National Agricultural Research Organization (NARO)/National Crops Resources Research Institute (NaCRRI), Kampala, Uganda.
Mwanga, R.O.M., B. Odongo, C.N. Niringiye, A. Alajo, B. Kigozi, R. Makumbi, E. Lugwana, J. Namakula, I. Mpembe, R. Kapinga, B Lemaga, J. Nsumba, S. Tumwegamire, and G.C. Yencho. 2009. 'NASPOT 7', 'NASPOT 8', 'NASPOT 9 O', 'NASPOT 10 O', and 'Dimbuka-Bukulula' sweetpotato. HortScience 44:828-832.

Mwanga, R.O.M., G.C. Yencho, and J.W. Moyer. 2002. Diallel analysis of sweetpotatoes for resistance to sweetpotato virus disease. Euphytica 128:237-248

Osiru, M.O., M.O. Olanya, E. Adipala, B. Lemaga, and R. Kapinga. 2009. Stability of sweet potato cultivars to Alternaria leaf and stem blight disease. J. Phytopathol. 157:172-180.

Ssemakula, G.N., A. Bua, Y. Baguma, S. Tumwesigye, W. Sserubombwe, T. Alicai, and C. Omongo. 2003. Farmer participatory evaluation in Uganda, p. 426-434. In: Proc. 8th International Society for Tropical Root Crops-Africa Branch (ISTRC-AB), Ibadan, Nigeria, Nov. 2001.

Tai, G.C.C. 1971. Genotypic stability analysis and its application to potato regional trials. Crop Sci. 11:184-190.

Thiele, G., E. van de Fliert, and D. Campilan. 2001. What happened to participatory research at the International Potato Center? Agr. Human Values 18:429-466

Witcombe, J.R., A. Joshi, and S.N. Goyal. 2003. Participatory plant breeding in maize: A case from Gujurat, India. Euphytica 130:413-422. 